DOI: http://dx.doi.org/10.21784/ZC.2018.008

\title{
Etykieta wizerunkowa
}

\section{w urzędach samorządu terytorialnego}

\author{
Image label in local government offices
}

\section{Streszczenie:}

W niniejszym opracowaniu podjęta została próba przeanalizowania jak ubiór urzędnika wpływa na wizerunek instytucji samorządowej. W dalszej części artykułu wskazano jak urzędnik samorządowy powinien ubierać się do pracy, jakie stosować dodatki, czego powinien się wystrzegać. Przedstawiono, jakie regulacje pracodawca może wprowadzić chcąc wymóc na pracownikach obowiązek stosowania stroju noszonego w codziennej pracy.

Słowa kluczowe: etykieta ubioru, wizerunek, urzędnik, ubiór, strój.

\begin{abstract}
:
This paper attempts to analyze how an employee's actual dress code influences the image of the local government. Further, it has been indicated how a local government official should dress for work; what accessories should be avoided. Regulations possible to be implemented by an employer for obliging the employees to abide by the dress code typical for daily work have been presented.
\end{abstract}

Keywords: dress code, image, clerk, dress, outfit.

\section{Wprowadzenie}

Kształtowaniu świadomości etycznej pracowników samorządowych służą kodeksy etyczne, sprzyjają formowaniu pożądanego wizerunku pracownika i urzędu. Urzędnik swoim postępowaniem i wyglądem 
Małgorzata Maruszewska - Etykieta wizerunkowa w urzędach samorzqdu...

powinien dawać świadectwo praworządności oraz współtworzyć wizerunek administracji samorządowej. Pracownicy urzędów samorządu terytorialnego w swojej codziennej pracy winni przestrzegać zasad dobrego wychowania, właściwego ludziom o wysokiej kulturze osobistej, poprzez swój profesjonalizm i zachowanie. Pożądane jest, aby starali się pogłębiać zaufanie petentów, dbali o swoją postawę etyczną i nienaganny wygląd osobisty, świadomie dostosowując jego elementy do powagi urzędu. Ubiór urzędnika to klasyka i stonowanie, a nie ekstrawagancja i brak skromności ${ }^{1}$.

Etyka zawodowa stanowi zespół zasad i norm określających, jak z moralnego punktu widzenia powinni zachowywać się przedstawiciele danego zawodu. W edukacji etycznej można wyróżnić dwie drogi2:

- próba zdyscyplinowania pracowników przez wprowadzenie odpowiednich regulacji, pod postacią kodeksu etycznego,

- rozszerzenie wrażliwości etycznej decydentów, np. przez propagowanie wzorców i nagród fair play.

Kodeks etyczny jest katalogiem standardów zachowań etycznych, który określa sposób postępowania i zachowania pracowników, jest zbiorem zasad i wartości etycznych wyznaczających standardy postępowania urzędników publicznych na rzecz realizacji interesu publicznego ${ }^{3}$. Stanowi on uporządkowany logicznie zbiór zasad etycznych, celem jego nie jest tworzenie nowych norm, lecz konkretyzowanie, uszczegóławianie norm etyki ogólnej do specyfiki danego zawodu.

To właśnie ustanowione kodeksy etyczne dotyczą zwykle takich zagadnień jak:

- określenie grupy zawodowej;

- obowiązki urzędników wobec społeczeństwa,

- zachowań w sytuacji powstania konfliktu interesu,

1 Załącznik do Zarządzenia Marszałka Województwa Kujawsko-Pomorskiego z dnia 31 stycznia 2011, nr 1/2011, Kodeks etyki pracowników Urzędu Marszałkowskiego Województwa Kujawsko-Pomorskiego, http://sejmik.kujawsko-pomorskie.pl/64/ kodeks-etyki-pracownikow-urzedu-marszalkowskiego-wojewodztwa-kujawsko-pomorskiego [dostęp: 7-08-2017].

${ }^{2}$ L. Zbiegień-Maciąg, Etyka w zarządzaniu, Warszawa 1996, s. 7.

${ }^{3}$ W. Borczyk, S. Kmak, M. Wójcik, [w:] J. Filek (red.), Etyczne aspekty działalności samorzq̨du terytorialnego, Kraków 2004, s. 85. 
- nadużywania władzy wynikającej z zajmowanej pozycji,

- wykorzystania zasobów publicznych dla korzyści prywatnych.

A co najważniejsze, zawierają również informację na temat wizerunku urzędnika. Są podstawowym źródłem informacji dla pracownika samorządowego o tym jak odpowiednio i nienagannie ubrać się do codziennej pracy, aby dobrze kreować nie tylko swój wizerunek, ale także instytucji, którą reprezentują, nie tylko w godzinach pracy, a także i poza nimi ${ }^{4}$.

\section{Historia dress code}

Określenie „dress code” pojawiło się w Polsce w latach 90. XX wieku, ale dla wielu osób nadal brzmi enigmatycznie ${ }^{5}$. Co oznaczają te dwa słowa? W słowniku angielsko-polskim pod hasłem "dress" znajdujemy czasownik „ubierać się”, ale także rzeczownik „ubranie” i „strój”. Słowo „code” oznacza m.in. „kodeks” lub „kod”. Tym samy w języku polskim „dress code" oznacza nic innego jak kodeks ubierania się.

Wraz z rozpowszechnianiem się dress code reguły doboru stroju stały się bardziej restrykcyjne i wymagające od pracownika gustu, elegancji i schludności. Strój powinien być dostosowany do wymogów przełożonego, zajmowanego stanowiska, wizerunku. Wygląd pracownika ma ogromny wpływ nie tylko na postrzeganie danej instytucji przez petenta, ale także poprawia jej wizerunek zewnętrzny.

Za trafne przyjąć należy, że dress code to wewnętrzne przepisy, które mają być wyznacznikiem dobrego ubioru pracownika, mogą być ujęte $\mathrm{w}$ formalny sposób, jako pisemny dokument skierowany do wszystkich pracowników, wyznaczający jasne zasady, w jakie kolory i jaki rodzaj ubrań należy ubierać się do pracy. Dress code reprezentuje wartości, do jakich instytucja się odnosi i jakie wyznaje. Przyczynia się także do zwiększenia kultury organizacyjnej oraz zapewnia poczucie

\footnotetext{
${ }^{4}$ Ibidem.

${ }^{5}$ K. Łoszewski, Dress code, Tajemnice męskiej elegancji, Olszanica, 2012, s. 144.

${ }^{6}$ P. Domański, Słownik angielsko-polski polsko-angielski + idiomy, Warszawa, 2004. s. 236 , s. 301.
} 
Małgorzata Maruszewska - Etykieta wizerunkowa w urzędach samorządu...

spełnienia standardów jakości w obsłudze petenta. Wewnątrz instytucji etykieta ubioru może być czynnikiem motywującym pracowników, poprzez poczucie przynależności do danej grupy zawodowej. Pozwala na uniknięcie dowolności i różnorodności w ubiorze, co może mieć dobry wpływ na większą dyscyplinę pracy. Warunkiem powodzenia jest jednak umiejętnie wprowadzenie przez pracodawcę zasad dress code i zaakceptowania ich przez pracowników. Zauważyć należy, że obecnie samorządy terytorialne nieczęsto wprowadzają kodeksy etyczne, tym bardziej rzadziej tworzą przepisy zawierające powszechnie obowiązujące zasady ubioru. Wyznaczenie sztywnych zasad dress code napotyka na coraz to częstsze słowo krytyki z ust urzędnika, który uważa, że w dobie XXI wieku wprowadzenie ubiorów służbowych jest nieeleganckie i mniej gustowne niż obowiązujący trend modowy

Oponenci etykiety ubioru coraz częściej zarzucają pracodawcom nadmierną ingerencję w życie osobiste i indywidualizm w sposobie ubierania się pracowników. Starając się odciążyć pracowników od etykiety ubioru m.in. w firmach zaczęto wprowadzać casual Fridays, czyli jeden dzień w tygodniu, zwykle piątek, w którym obowiązuje strój określany mianem bardziej swobodny. Luźne piątki obowiązują głównie w biurach dużych korporacji, jednak także i tam, pracownicy mający kontakt z klientami ubierają się zgodnie z etykietą obowiązującą przez cały tydzień.

Zasady firmowego dress code'u można także sformułować w wewnętrznej instrukcji lub nawet $\mathrm{w}$ umowie o pracę. Pracownik powinien je poznać przed podpisaniem umowy. Pracodawca ustanawiając zasady ubioru w danej instytucji nie powinien przy tym przekroczyć granicy dobrego smaku. Zgodnie z art. $11^{1}$ k.p. musi szanować godność i inne dobra osobiste swoich pracowników ${ }^{8}$.

\subsection{Rola ubioru}

Ubiór odgrywa znaczącą rolę społeczną będącą wyraźnym komunikatem zrozumiałym dla większości członków społeczeństwa. Służył

\footnotetext{
${ }^{7}$ K. Łoszewki, Dress code..., op. cit., s. 194.

${ }^{8}$ Ustawa z dnia 26 czerwca 1974 r., Kodeks pracy, Dz.U. 2016, poz. 1666, tj., LEX.
} 
nie tylko jako ochrona przed zimnem i skrywał nagość, ale od zawsze był sposobem na wyrażanie swojego odrębnego ja i służył akcentowaniu pozycji w hierarchii społecznej. Niektórzy antropolodzy twierdzą, że pierwotnym celem ubierania było zwrócenie uwagi na sfery erogenne a nie ukrywanie ich. Ta funkcja pojawiła się dopiero później. Ubiór zawiera w sobie szereg informacji dotyczących nie tylko dochodów i statusu społecznego, ale także przynależności do określonej warstwy społecznej czy zawodowej, pochodzenia etnicznego, religijnych przekonań i wielu innych aspektów życia.

Należy podkreślić bardzo ważną nie tylko zewnętrzną, ale i wewnętrzną rolę ubioru. Odpowiednio dobrany strój wzmacnia nasze przekonania o kompetencjach i zwiększa skuteczność działania. Naukowcy sformułowali teorię zwaną „enclothed cognition”, która oznacza, iż ubiór mając symboliczne znaczenie sprawia, iż osoba go nosząca podświadomie wczuwa się w rolę jaką strój narzuca9. Zgodnie z pewnym eksperymentem przeprowadzonym w Kalifornii na grupie policjantów, którym zmieniono mundury na bardziej „cywilne” okazało się, że nowy strój zmienił sposób zachowania policjantów na mniej agresywny, spadła liczba interwencji, w których doszło do zranienia osób cywilnych. Policjanci stali się bardziej komunikatywni i łagodniejsi. Niestety okazało się także, że spadła ich skuteczność, jakby brak munduru osłabił ich bojowość i aktywność. W tym przypadku mundur dodatkowo wzmacniał autorytet wymuszając posłuszeństwo ${ }^{10}$.

Naukowcy udowodnili także ścisły związek między strojem a nastrojem. Opublikowany na początku 2012 roku raport naukowców z brytyjskiego uniwersytetu Hertfordshire potwierdził te zależności. Profesor Karen Pine kierująca badaniami stwierdziła, że osoby w dobrym nastroju wybierają zupełnie inne elementy stroju, takie, które pozwalają nas dostrzec, wyróżniając z tłumu. Kobiety szczęśliwe wyraźnie odzwierciedlają swój nastrój odpowiednim, choć często podświadomie wybieranym strojem, który podkreśla ich atrakcyjność.

${ }^{9}$ K. Danowska, Krótka historia języka ubioru, https://www.dresscode.pl/blog-dressschool/krotka-historia-jezyka-ubioru [dostęp: 5-07-2017].

${ }^{10}$ Ibidem. 
Małgorzata Maruszewska - Etykieta wizerunkowa w urzędach samorządu...

Ekonomista David Marks stwierdził, „wygląd-uroda jest siłą społeczną równie potężną jak rasa czy płeć. Ale w przeciwieństwie do rasizmu czy seksizmu uprzedzenia związane $\mathrm{z}$ wyglądem - funkcjonują w sposób nieuświadomiony"11.

\section{Ubiór urzędnika}

Pierwszym wyznacznikiem elegancji jest, według jej najbardziej klasycznej definicji umiar i prostota, drugą przesłanką jest staranność $\mathrm{w}$ ubiorze ${ }^{12}$. Urzędnik powinien respektować obie zasady w codziennej pracy, niestety coraz częściej żadna z tych przesłanek nie jest wdrażana w życie. Odpowiedni ubiór to tak naprawdę przyjęty w danym środowisku, stosowny do wykonywania danego zawodu ${ }^{13}$. W pracy urzędnika wyróżnianie się swoim ubiorem jest niemile widziane, nie może więc być on ekstrawagancki ani szokujący otoczenie. Elegancja w stroju to bowiem dobry smak, wygoda i pewien indywidualizm wynikający z osobowości. Strój powinien być odpowiednio dobrany kolorystycznie i raczej stonowany. $W$ codziennej pracy urzędnik powinien unikać tzw. kolorów wakacyjnych: jaskrawych i kontrastowych. Kolorem pożądanym jest biel i kolory pastelowe, które łagodzą ubiór i są jego naturalnym dopełnieniem, nie należy nosić ubrań w kolorze żółtym, określanym mianem koloru drażniącego, brązowy uważany jest także jako kolor nijaki i zupełnie pozbawiony strategicznego znaczenia. Przeciwieństwem jest kolor granatowy, który traktowany jest jako niezwykle profesjonalny, szczególnie w połączeniu z błękitnymi dodatkami.

W urzędach powinny dominować kolory ciemne. Poza bielą, granatem i odcieniami błękitu preferowane są także: kolor szary i beż. Jeśli urzędnik nie chce dominować nad petentem powinien wybierać ubrania właśnie w kolorze szarym. Oczywiście w różnych nasyceniach

\footnotetext{
${ }^{11}$ N. Etcoff, Przetrwaja najpiękniejsi, Warszawa 2000, s. 267-268.

${ }_{12}$ T. Orłowski, Protokół dyplomatyczny. Ceremoniał \& Etykieta, Warszawa 2005, s. 314-315.

${ }^{13}$ K. Czerwińska, A. Kwiatkowska, Ubiór dla pracownika w interpretacjach i orzeczeniach, http://kwartalnikrsk.pl/assets/rsk1-2016-czerwinska\%2C-kwiatkowska.pdf [dostęp: 7-08-2017].
} 
szarości. Jeśli negocjacje, rozmowy, spotkania mają partnerski przebieg należy unikać kolorów ciemnych mogących wzbudzić niepotrzebny dystans. Szary budzi zaufanie, jest neutralny, odczytywany jako kolor przyjazny i niezagrażający naszej osobowości. Czerń powinna być stosowana z umiarem. Ciemny kolor buduje prestiż, dodaje powagi. Kolory poszczególnych części garderoby powinny tworzyć harmonię ${ }^{14}$.

Ubiór podkreśla wiarygodność i ma wielki wpływ na ocenę urzędnika przez petenta. Ubiór zawsze powinien być dopasowany do okoliczności w jakich chcemy w nim wystąpić. Stroje zostały podzielone na trzy kategorie:

- strój nieformalny,

- strój formalny,

- strój koktajlowy.

W urzędach samorządu terytorialnego powinien dominować właśnie strój nieformalny (ang. business dress, informal wears), odpowiada on częściej stosowanemu w języku polskim pojęciu ubrania wyjściowego, czyli noszonego poza domem. Nosimy go do godziny 20:00. Strojem nieformalnym jest:

- dla mężczyzn garnitur i krawat,

- dla kobiet krótka sukienka (sięgająca do kolan) czy kostium ze spódnicą lub ze spodniami. Coraz częściej kobiety ubierają się w dwuczęściowe kostiumy. Damski kostium zwany żartobliwie mundurkiem, jest powszechnym typem kobiecego stroju nieformalnego z racji wygody, uniwersalności i przesłania ${ }^{15}$.

\subsection{Błędy popełnianie w ubiorze}

Czy tego chcemy, czy nie, ubiór stanowi swoistą wizytówkę naszego statusu społecznego, powagi reprezentowania instytucji i szacunku dla wykonywanego zawodu. Dbałość o estetyczny wygląd, schludność i elegancja buduje nie tylko autorytet osobisty, ale także instytucji, którą się reprezentuje. Ubiór stał się więc siłą rzeczy istotnym elementem

\footnotetext{
${ }^{14}$ M. Żukowski, Problematyka ubioru urzędnika, artykuł ST/2009/9/20-25, LEX.

15 T. Orłowski, Protokół dyplomatyczny. Ceremoniał \& Etykieta, Warszawa 2005, s. 314-315.
} 
Małgorzata Maruszewska - Etykieta wizerunkowa w urzędach samorządu...

savoir vivre'u, jest wizytówką każdego urzędnika samorządowego. Niestety wiele osób zapomina o bardzo ważnych detalach, które potrafią popsuć nawet najlepiej dobrany zestaw ${ }^{16}$.

Stosując zasady etykiety biznesowej mężczyźni powinni zwracać uwagę na długość spodni (jedna, dwie fałdy z przodu na bucie dają nam prawidłową długość spodni z tyłu - powinny zakrywać połowę obcasa - 1 cm nad ziemią), długość marynarki (prawidłowo dobrana powinna, patrząc na nią z tyłu, zakrywać połowę długości od szyi i ramion do butów). Panowie bardzo często niestety zapominają o odpowiedniej długości krawata i skarpetek. Krawat przy wyprostowanej sylwetce powinien sięgać mniej więcej do paska od spodni (nie krótszy). Należy również zwrócić uwagę na kolorystyczne dopasowanie do reszty stroju, wzór i kolor musi harmonizować z koszulą i marynarką. Bardzo częstym błędem jest zakładanie koszuli z guzikami przy kołnierzyku i zawiązywanie do niej krawata. Jeśli chodzi o skarpetki muszą być one na tyle długie, aby przy siadaniu nie była widoczna goła łydka. Skarpetki dobieramy pod kolor spodni. Niezależnie od płci w stroju urzędnika nie powinniśmy sięgać po koszule z innym rękawem niż długi. Nawet pod marynarkę. Nawet latem. Co bardziej odważni w okresie letnim decydują się na skrócenie długości nogawek u spodni, czy też zakładają krótkie spodenki. W sposób oczywisty jest to sprzeczne z zasadami ubioru urzędników. Wyboru takiego nie uzasadnia nawet wyższa temperatura, czy brak klimatyzacji w biurze ${ }^{17}$.

Kobiety w codziennej pracy w samorządzie powinny zapanować nad długością spódnic (przy siadaniu powinna ona kończyć się $1 \mathrm{~cm}$ nad kolanem), krojem bluzek (nie powinny one odsłaniać biustu, nie mogą mieć zbyt frywolnego kroju, muszą być klasyczne i eleganckie). Długości spódnic i spodni w tzw. wariancie 7/8 czy 3/4 nie są tratowane jako strój elegancki. Do urzędu kobiety powinny zakładać rajstopy w kolorze cielistym, popielatym lub szarym. Powinny być matowe lub półmatowe. Rajstopy we wzorki, z nadrukami czy w kolorze czarnym nie powinny

\footnotetext{
${ }^{16}$ M. Żukowski, Problematyka ubioru..., op. cit.

${ }^{17}$ Etykieta wizerunkowa $w$ urzędach, http://instytutdyplomacji.net/aktualnosci/ szkolenia [dostęp: 4-08-2017].
} 
być zakładane do pracy w urzędzie. Problem z wyborem ubrania pojawia się przede wszystkim w okresie letnim i niestety dotyczy najczęściej kobiet. Bluzki na ramiączkach, z odkrytymi plecami, wykonane z prześwitujących materiałów to nie strój urzędnika. Pod białe bluzki najlepiej zakładać cielisty biustonosz, wtedy nie zwraca on na siebie uwagi ${ }^{18}$.

W stroju nieformalnym nie ma miejsca na sandały, czy obuwie sportowe i kozaki. Zarówno u mężczyzn, jak i u kobiet. W okresie letnim należy chodzić w zakrytych butach. Powinny dominować półbuty, czółenka i szpilki. Jeśli chodzi o szpilki to należy zwrócić uwagę na długość obcasa (6-7 cm, nie więcej). Zimą kozaki należy zamienić na elegancie botki, panowie powinni w pracy zrezygnować z chodzenia w ocieplanych butach, zamieniając je na buty bez ociepliny. Niedoprasowane spodnie i pognieciona koszula, niezgrane kolory, brudne buty, to samo ubranie noszone codziennie nie oznaczają skromności, lecz karygodną abnegację. Należy dbać, aby noszone rzeczy były czyste i świeże ${ }^{19}$. Zwracać należy także uwagę aby noszone ubrania nie były za duże, lecz dopasowane do sylwetki osoby, która je nosi, jej walorów zewnętrznych, wieku i okoliczności ${ }^{20}$.

\subsection{Dodatki}

Staranność w ubiorze nie sprowadza się do wyłącznie do dbania o stan w jakim znajduje się nasze ubranie. Strój powinien harmonizować z dodatkami takimi jak: krawat, obuwie, rękawiczki, torebka, makijaż, biżuteria, perfumy. Nie mogą one zbyć liczne i zbyt ostentacyjne, bo przyniosą odwrotny efekt.

W kwestii stosowania dodatków kobiety mają przewagę nad mężczyznami. Dodatkiem do kobiecego stroju mogą być bowiem m.in. biżuteria, obuwie, rękawiczki, torebki, paski. Ważnym kobiecym dodatkiem do stroju są również makijaż i perfumy. Makijaż stosowany przez panie powinien być bardzo oszczędny, tzw. dzienny, naturalny. Powinien przetrwać bez zmian przez cały czas pracy, a w razie potrzeby powinno

\footnotetext{
${ }^{18}$ Ibidem.

${ }^{19}$ Ibidem.

${ }^{20}$ T. Orłowski, Protokół dyplomatyczny..., op. cit., s. 319.
} 
Małgorzata Maruszewska - Etykieta wizerunkowa w urzędach samorządu...

się nanieść poprawki ${ }^{21}$. Jaskrawe szminki, czy cienie do powiek, powinny ustąpić miejsca delikatnym kolorom pastelowym. Jeśli panie zdecydują się na pomalowane paznokcie, powinny one także być w kolorach pastelowych, chociaż i tak najbardziej pożądanym kolorem będzie tutaj kolor bezbarwny ${ }^{22}$.

Zasady doboru dodatków przez mężczyzn są już bardziej restrykcyjne. Często mówi się o „zasadzie trzech S”. Mężczyźnie wypada bowiem jako dodatek stosować jedynie: spinki i to wyłącznie do mankietów, jeśli zakładają szelki nie mogą być one prezentowane ostentacyjnie, lecz ukryte pod marynarką lub kamizelka, skarpetki, które powinny być dobrane kolorystycznie do spodni i butów, kolorystyka oczywiście jednobarwna, a nie wzorzysta. Mężczyźni powinni zachować wstrzemięźliwość w noszeniu biżuterii. Odradza się noszenia złotych łańcuchów nie tylko na nadgarstku, ale także na szyi oraz ozdób na rękach, za wyjątkiem obrączki ślubnej, sygnetu rodowego. Wybierając zegarek do pracy urzędnik powinien wybrać model klasyczny, który nie rzuca się w oczy jako symbol statusu. Z biżuterią nie powinny przesadzać także kobiety, rezygnując z długich korali, brzęczących bransolet ${ }^{23}$.

Krawat jako dodatek powinien być w szczególności odpowiednio dobrany kolorystycznie, nie bez znaczenia pozostaje tkanina z której jest wykonany. Mężczyzna do pracy w urzędzie powinien wybierać krawat wykonany z tkanin naturalnych, na których nie będzie widać deformacji, takich jak zagniecenia. Absolutnie niewłaściwym jest używanie do krawata dekoracyjnych szpil lub szpilek ${ }^{24}$.

\section{Ubiór - zagadnienie prawne}

Odpowiedni ubiór urzędnika nie jest wyłącznie jego sprawą, nie ogranicza się też do tzw. „dobrego smaku”, wyczucia czy też kryteriów estetycznych, ale w coraz większym zakresie jest zagadnieniem prawnym ${ }^{25}$.

\footnotetext{
${ }^{21}$ M. Żukowski, Problematyka ubioru..., op. cit.

${ }^{22}$ Ibidem.

${ }^{23}$ C. Ikanowicz, J. Piekarski, Protokół dyplomatyczny i dobre obyczaje, Warszawa 2004, s. 194.

${ }^{24}$ Ibidem.

${ }^{25}$ M. Żukowski, Problematyka ubioru..., op. cit.
} 
Pracownik powinien ubierać się odpowiednio do wykonywanej pracy. Ze względu na warunki pracy, pracodawcy często zapewniają swoim pracownikom określone ubiory. Podkreślić należy, że nie dzieje się to jednak zbyt często w pracy urzędnika samorządowego. Ubiór służbowy, bo tak jest często określany, wprowadzono w kilku urzędach w Polsce, m.in. w Urzędzie Gminy w Włoszczakowicach (woj. wielkopolskie). „Mundur” urzędników we Włoszczakowicach jest finansowany przez pracodawcę, który wypłaca ekwiwalent pieniężny i dostarcza materiały na ubranie. Dla właściwego zapewnienia higieny wypłaca on również ekwiwalent za czyszczenie i pranie ubioru służbowego. Ubiór kobiety-urzędnika składa się tam z białej bluzki z kołnierzykiem z długim lub krótkim rękawem, prostej spódnicy o długości do kolana, dopasowanej kamizelki lub marynarki, czarnych pełnych butów na średnim obcasie, a mężczyzny z niebieskiej koszuli z długim rękawem, krótkiej kamizelki, marynarki i spodni, granatowego krawata $\mathrm{z}$ herbem gminy i czarnych sznurowanych butów.

Strój urzędnika w gdańskim ratuszu tworzą ciemne marynarki, spódnice lub spodnie, białe bluzki, dodatkami są krawat i apaszki $\mathrm{z}$ herbem miasta ${ }^{26}$.

W standardach obsługi klienta w Urzędzie Miasta Jedlin-Zdrój, zgodnie z § 9.1. zarządzenia nr 49/2010 Burmistrza Miasta Jedlina-Zdrój z dnia 16 sierpnia 2010 r. przyjęto, że „wygląd zewnętrzny pracownika samorządowego jest wizytówką Urzędu, stosowany ubiór i schludny wygląd ma wpływ na wiarygodność pracowników i budzi zaufanie klientów, styl ubierania winien być adekwatny do zajmowanego stanowiska, uwzględniać prestiż miejsca, w którym pracuje urzędnik, tworzyć spójny budzący zaufanie wizerunek biura"27.

Jednym z powodów, dla których pracodawca zapewnia strój służbowy pracownikowi jest zamiar wprowadzenia odpowiednich standardów obsługi petenta. Niepodporządkowanie się wymaganiom

${ }^{26}$ Ibidem.

${ }^{27}$ Zarzq̨dzenie nr 49/2010 Burmistrza Miasta Jedlin-Zdrój z dnia 16 sierpnia 2010 r. w sprawie wprowadzenia katalogu standardów zachowań urzędnika w Urzędzie Miasta Jedlin-Zdrój, http://www.bip.um.jedlina.pl/UserFiles/File/Zarzadzenia_2010/Zarzadzenie.Nr.49.2010.Katalog.zachowan.urzednika.doc [dostęp: 4-08-2017]. 
Małgorzata Maruszewska - Etykieta wizerunkowa w urzędach samorządu...

stawianym przez pracodawcę (niestety w urzędach samorządowych bardzo rzadko, jak wyżej wskazano wprowadza się wymóg stroju służbowego) może skutkować karą. Artykuł 100 § 2 k.p. mówi o obowiązku pracownika polegającym na dbałości o dobro firmy, w zakresie którego mieszczą się również starania o schludny i elegancki wygląd tych osób, które na co dzień mają kontakty z petentem ${ }^{28}$. Zasady ubierania się urzędnika samorządowego mogą być wprowadzane np. do obowiązującego regulaminu pracy, na podstawie art. 104 kodeksu pracy. ${ }^{29}$ Rzadziej regulacje te mogą mieć charakter bardzo ogólnych wskazówek. Czasami zdarza się, że pracodawca wprowadza zapis dotyczący zakazu noszenia do pracy m.in. spodni dżinsowych, spodenek i krótkich spódnic. Bywają zapisy jeszcze bardziej ogólne, które dotyczą tylko kultury osobistej, wskazując na obowiązek schludnego ubierania się. Rzadkością jest wprowadzanie uniformów z herbem miasta, jak wcześniej wskazano taką regulację wprowadzono w gdańskim ratuszu.

Jeżeli obowiązek zapewnienia ubrania wynika $\mathrm{z}$ obowiązujących przepisów, sprawa jest prosta, przepisów tych musi przestrzegać i pracodawca i pracownik. Jeżeli pracodawca wprowadza obowiązek noszenia określonego stroju bez wyraźnej podstawy prawnej, powstaje pytanie, jak daleko posuniętą swobodę posiada w tym zakresie. Przyjmuje się, że obowiązek noszenia określonego stroju może być nałożony przez pracodawcę, jeżeli ma to wpływ na kreowanie wizerunku instytucji. Niespełnienie tego warunku powoduje, że pracodawca nie może skutecznie domagać się od pracownika określonego stylu ubierania ${ }^{30}$. Zgodnie z Kodeksem pracy „Pracownik jest obowiązany wykonywać pracę sumiennie i starannie oraz stosować się do poleceń przełożonych, które dotyczą pracy, jeżeli nie są one sprzeczne z przepisami prawa lub umową o pracę"31. W tym miejscu wskazać należy, że pomimo powyższej regulacji, urzędnik, który jest pracownikiem samorządu terytorialnego „zawsze”, niezależnie od uregulowań prawnych powinien

\footnotetext{
${ }^{28}$ Ustawa z dnia 26 czerwca 1974 r. Kodeks....

${ }^{29}$ Ibidem.

${ }^{30}$ K. Czerwińska, A. Kwiatkowska, Ubiór dla pracownika..., op. cit.

${ }^{31}$ art. $100 \S 1$ k.p.
} 
reprezentując urząd wyglądać w sposób reprezentacyjny, stroniąc od przepychu, zbytniej nonszalancji i nadmiernego roznegliżowania.

\section{Podsumowanie}

W talmudzie babilońskim uznano, że „chwałą Boga jest człowiek, chwałą człowieka jest ubiór". Z kolei zgodnie z przysłowiem perskim: „wygląd zewnętrzny człowieka to strona tytułowa jego wnętrza”. Ubiór podkreśla wiarygodność i ma wielki wpływ na ocenę urzędnika przez pracodawcę i petentów. Urzędnik w codziennej pracy powinien nosić strój nieformalny, zwracając szczególną uwagę na odpowiednie dodatki, wystrzegając się przy tym błędów popełnianych w ubiorze, respektować przyjęte regulacje prawne dotyczące ubioru, a w przypadku ich braku mając na względzie powagę instytucji, którą reprezentuje zawsze starać się, aby jego wizerunek był nienaganny, pozbawionych jakichkolwiek ułomności.

\section{Bibliografia:}

Borczyk W., Kmak S., Wójcik M., [w:] J. Filek (red.), Etyczne aspekty działalności samorzq̨du terytorialnego, Wyd. MSAP AE, Kraków 2004.

Czerwińska K., Kwiatkowska A., Ubiór dla pracownika $w$ interpretacjach $i$ orzeczeniach, http://kwartalnikrsk.pl/assets/rsk1-2016-czerwinska\%2C-kwiatkowska.pdf.

Danowska K., Krótka historia języka ubioru, https://www.dresscode.pl/blog-dressschool/krotka-historia-jezyka-ubioru/.

Domański P., Słownik angielsko-polski polsko-angielski + idiomy, Wyd. Wilga, Warszawa 2004. s. 236, s. 301.

Etcoff N., Przetrwają najpiękniejsi, Wyd. CiS, W.A.B., Warszawa 2000.

Etykieta wizerunkowa $w$ urzędach, http://instytutdyplomacji.net/aktualnosci/szkolenia/.

Ikanowicz C, Piekarski J., Protokół dyplomatyczny i dobre obyczaje, Warszawa 2004.

Łoszewski K., Dress code, Tajemnice męskiej elegancji, Wyd. Bosz, Olszanica 2012. 
Małgorzata Maruszewska - Etykieta wizerunkowa w urzędach samorządu...

Orłowski T., Protokół dyplomatyczny. Ceremoniał \& Etykieta, ADMSZ, Warszawa 2005.

Ustawa z dnia 26 czerwca 1974 r., Kodeks pracy, Dz.U. z 2016, poz. 1666, LEX.

Załącznik do Zarządzenia Marszałka Województwa Kujawsko-Pomorskiego z dnia 31 stycznia 2011 r., nr 1/2011, Kodeks etyki pracowników Urzędu Marszałkowskiego Województwa Kujawsko-Pomorskiego,http:// sejmik.kujawsko-pomorskie.pl/64/kodeks-etyki-pracownikow-urzedumarszalkowskiego-wojewodztwa-kujawsko-pomorskiego.

Zarządzenie nr 49/2010 Burmistrza Miasta Jedlin-Zdrój z dnia 16 sierpnia 2010 r. w sprawie wprowadzenia katalogu standardów zachowań urzędnika w Urzędzie Miasta Jedlin-Zdrój, http://www.bip.um.jedlina.pl/UserFiles/ File/Zarzadzenia_2010/Zarzadzenie.Nr.49.2010.Katalog.zachowan.urzednika.doc.

Zbiegień-Maciąg L., Etyka w zarzq̨dzaniu, Wyd. CIM, Warszawa 1996.

Żukowski M., Problematyka ubioru urzędnika, artykuł ST/2009/9/20-25, LEX. 